\title{
GREEKS AND THE GREEKS
}

To make generalisations, whether in speech or in print, is always a dangerous thing to do - dangerous not only in everyday affairs but also in scholarly research. All too frequently we are inclined to draw general conclusions from a larger or smaller number of special cases. Because the living voice of an age long past is no longer there to put us right, this inclination has become, from a danger, a positive menace in the study of history; and not least is it present in modern scholarship as concerned with ancient Greece.

The history of the ancient Greeks covers at least a millennium. Historians usually cut it up into large sections - the archaic, the classical, the Hellenistic, and the Roman periods (to which one might perhaps add the Byzantine). In each of these periods it is possible to distinguish differences which mark it off from the preceding and succeeding periods. That these criteria are sometimes rather arbitrary is not our present concern. But in one of these periods (and one which, even as things are, is by itself a matter of controversy), "standardised" Greeks have been created; this procedure is even more questionable, and it is this which forms the subject of the following discussion.

During the last two centuries, ever since modern historical study directed its attention to the ancient Greeks, we have had presented to us a standard picture of Greek civilisation, particularly in the case of the classical period of the 5 th and 4 th centuries B.C., a picture which in various ways fails to correspond with the facts as handed down in the ancient sources. Because it is these very centuries - to which the 6th might possibly be added - which are with justice regarded as the greatest and most impressive in the course of Greek civilisation (this being the age when Greek philosophers and poets, statesmen and artists created "the Greek miracle") it might be useful to consider to what extent our historical picture has been falsified by generalisations 
made about classical Greece. It is in fact a practical investigation of a strict historical kind. But it may also be conceived in more general and theoretical terms; we may ask, for instance: Are these philosophers and poets, these statesmen and artists, "Greeks" or "the Greeks"? In other words: Does history consist of the lives of great men only, and of what happens to them, or do we include the little man as well? These larger questions are deliberately avoided here. For this article a very provisional investigation, a practical reconnaissance of a small section of the field, offers sufficient material.

Before we embark on it, however, a little must be said about some particular ways in which these generalisations about the Greeks in the heyday of ancient Hellas make their appearance; they are not always the same. There are three which especially demand attention. Most classical philologists and historians see in Greek civilisation an evolution from(or a revolution against) the East, a political, intellectual and artistic awakening from the results of which our Western civilisation still profits daily: in the political sphere a balance between the power of the state and the freedom of the individual; in science a discovery of the mind, a progress from mythical towards rational thinking, a beginning of free and objective scientific investigation; in art a sense of harmony and proportion, of that which in the most direct meaning of the words is known as "le miracle grec". - Now I have no wish, in any way, to suggest that this vision is wide of the truth; on the contrary, it is a vision I share. But I am inclined to wonder if it is the whole truth. The question is all the more justified because the claim is all too frequently made that it is indeed the whole truth.

A result of the generalising about the Greeks was to idealise them, and this has had unexpected consequences. Some - they form the second group - concentrated their enthusiasm for the Greeks on one aspect of Hellenic culture. German scholars, in particular, have concentrated their attention on one part of the manysided spiritual life of the Greeks, on religion, and on religion in its most exuberant expression; that is on one particular god, Dionysus. This enthusiasm, which became practically a mania, affected their treatment of political history. In their admiration they focussed their research on those periods in which, according to them, the worship of the gods of the mysteries was at its most exuberant, and particularly on the Hellenistic period. The result of this, in turn, was to lead many exponents of this line of thought to disparage Greek democracy, the city state and its liberties; no longer was there any appreciation for the austerity of form, for the moderation and balance, or, in particular, for the unsteady equilibrium which some cities attained in their political structure only with the greatest difficulty. - Let no classical scholar of 
the old school say that the work of this "second group" was merely negative. After all, we owe to it Rohde's Psyche, Nietzsche's Geburt der Tragödic and W. F. Otto's Götter Griechenlands. Nor should he point to the many unsuccessful books written by adherents of the same "faith", compared with which the works mentioned are no more than the exceptions. Let him rather look first to himself. It cannot be denied that a field neglected by the first group was opened up by the second. Our knowledge was enriched and our insight deepened. Our attention was directed to an aspect of the spiritual life unnoticed or neglected by the old approach.

But fiercer by far than the struggle against the "extatici" is the battle which the champions of the old approach to the classical age must wage against the historical-materialists. Ever since Marx and Engels, the followers of this "third way" have turned their backs on the traditional vision of the classicist. Greek civilisation was analyzed in their own camp and the results of this analysis have been published over and over again with scarcely any alterations. The classicists of Western Europe cannot remain blind to the fact that half the world makes its acquaintance with the ancient Greeks through books steeped in historical-materialistic doctrines. It is a more bitter pill for them, that they cannot avoid conceding that the new doctrine does, indeed, emphasize certain factors in the history of Hellas which they have neglected. When, for example, a prominent English scholar voices the opinion that only the poetic genius of Euripides was able to fathom the religion of Dionysus, and that the man in the street could not comprehend its religious depths, it is high time for someone to point out the importance of the little man and of the slave in the development of the religious life; one must take the social structure of the Greek community into account, as well as its economic life, which again is something still too often looked upon as being of secondary importance. ${ }^{1}$

It is in this particular field of the cult of Dionysus that, in one matter of detail, I should like to suggest a possible explanation to be found in the spheres both of psychology and of economics. In this connection I refer to the pallophoria which formed part of certain fertility rites at the Dionysiac Festivals in Athens. ${ }^{2}$ I choose this example with an easier conscience because, as far as I know, the historical-materialists

1 W. K. C. Guthrie, The Greeks and their Gods, 1950, p. 166 for Euripides; H. Bolkestein, Economisch Leven in Griekenlands Bloeitijd, 1923, (Engl. translation: Economic Life in Greece's Golden Age, 1958), passim, for the underestimation of the economic factors.

${ }^{2}$ Further data in L. Deubner, Attische Feste, 1932, P. I35. 
have not dealt with it; this avoids any conflict between the differing points of view.

Literature and vase paintings demonstrate the significance of the phallos as a symbol of procreation in the agrarian religion of the Greeks, not least in the 5 th and $4^{\text {th }}$ centuries. The most obvious explanation is that the Greek farmer combined the life of plant, animal and man in one metaphor: the field was the womb, the ploughshare the phallos. Is this only a question of symbolism, or did the phallos play a significant role on its own account in the procession at the Dionysiac Festival? Apparently the latter was the case. Otherwise, why should a group of Athenian citizens sent out to form a new colony be instructed to send a wooden phallos each year to the mother country? ${ }^{1}$ The custom may perhaps be explained as follows. ${ }^{2}$ Many psychiatrists state that symbols arise from unsatisfied longings. In this way the available is the symbol of the non-available. In our Western European social relationships hunger and thirst do not exist: food and drink are everywhere available. Here the clinical psychiatrists recognize in food and drink the symbols of sexual desire. It does not seem out of place to assume a reversal of these relationships in Greek society. There food and drink were necessities of life that were often lacking; a Greek would often encounter famine and thirst, if not personally, then through the experience of others. Because of the climate and the outdoor life, and especially in sport and games, the genitals were not concealed. On the contrary, they might be seen daily; in other words they were "the available". Desire was focussed on food and drink, since they were often not available. If this explanation is correct then it appears that the significance of the phallopboria remains unchanged, but it proves to be very closely connected with social life, and even with the very existence of the community. The innumerable vases depicting ithyphallic figures and animals do not testify only to a sense of the burlesque and to vulgar exuberance - though I do not wish to exclude these elements. But vases and inscriptions also illustrate the precarious situation of the Greek world, and even of Athens in its heyday, with regard to food. We come to understand as a result why colonies of citizens abroad had to furnish a phallos among the yearly offerings; they remained members of the

1 Brea in Thrace in the year $449 / 8$, I.G., $\mathrm{I}^{2}, 45(=$ M.N. Tod, Greek Historical Inscriptions, $\mathrm{I}^{2}, 1946$, No. 44; for the date see A. G. Woodhead, The site of Brea: Thuc. I, 6I, 4, Class. Quart, N.S., II I952, p. 57-62). For the same custom on Delos, see M. P. Nilsson, Griechische Feste, I906, p. 28 I.

2 For the following, see E. R. Goodenough, Jewish Symbols in the Greco-Roman Period, vol. VI (Fish, Bread and Wine), New York 1956, p. I22; for the phallos see p. 18 et seq. 
community which had sent them out. Even if they did not remain members, they shared the general dangers of imminent famine equally with those who had stayed behind. ${ }^{1}$

If the phallos suggests the desire for the unavailable, sometimes also the unattainable, its function in sex life renders it eminently suitable to become the symbol of life in the absolute sense, of immortality. In the cult of Dionysus it plays an important role, even for an educated public which was offended by the exuberance of sexual behaviour among the people in general. It is probable that, among the upper classes the true meaning of the pballophoria was connected with the striving for union with the god and immortality. Heraclitus may have referred to this when he said: "If it were not Dionysus for whom they held the procession and sang the song in honour of the phallos, then what they did would be shameless." 2 One of the most eminent authorities on the subject believes that Euripides sought to argue that personal immortality could be attained only by union with the deity, and that his Bacchae can therefore only be understood if one detaches oneself from thoughts of the excessive sexuality of satyrs and sileni. ${ }^{3}$ Although I wish to avoid a discussion of the thorny problem of what Euripides meant in this play ${ }^{4}$, I believe it impossible to maintain such a sublimation theory in the case of all the characters in it. Even if Euripides aimed at any sublimation, it remains true that the view of Dionysus as the god of crude excess existed in his time. The Athenians were not all like Euripides, the Ephesians not all like Heraclitus. These great men were Greeks, they were not representative of the Greeks. Their lives and works, moreover, demonstrate most clearly that they occupied a special place in the society to which they belonged. Presumably, therefore no-one would object if they are considered as individual

1 The above was submitted to my colleague J. H. van den Berg, who, as a psychiatrist, in no way rejected this reversibility (food and drink are the symbols of the phallos, but the phallos is also the symbol of food and drink). He kindly drew my attention to a statement of his teacher Professor H. C. Rümke, who went even further than I believed to be possible in my suggestion. Rümke accepts the symbolism inherent in the phallos itself, but he is sceptical about symbols that are supposed to indicate the phallos. "It is, therefore, certainly not correct to say of certain symbols that they symbolize the phallos. The phallos itself is more likely to appear as a symbol." (See Rümke, Studies en Voordrachten, 1943, p. 217 et seq., and J. H. van den Berg in: Persoon en Wereld, Bijdragen tot de phaenomenologische psychologie, 1953, p. 220). An historian does well to take no part in these controversies. In any case, it is curious to observe that in view of Rümke's words my suggestion as to the significance of the frequently reproduced phallos is more acceptable to him than the symbolism of food and drink accepted by many of his colleagues.

2 Fragm. Is (Diels).

${ }^{3}$ E. R. Dodds' edition of the Bacchae, 1944, p. x.

4 In principle, I agree with J. C. Kamerbeek, Euripides en het probleem der Bacchen in: Antieke Tragedie, 1946, p. 96 et seq., and with F. Chapouthier, Euripide et l'accueil du divin, in: La notion du divin, 1954 , p. 205 et seq. 
personalities, no matter how closely bound to their community their actual existence may have been.

It is quite a different matter, however, once one comes to deal with social institutions and not with the personal work of a philosopher or of a poet. A glance at the field of constitutional history, particularly of Athens, reveals how opinions conflict, now even more fiercely than ever. Twenty-five years ago the Dutch historian Bolkestein reviewed the newly-published book of his compatriot Loenen, Vrÿbeid en Gelijkbeid in Atbene; he held that the author was pushing a door already open in arguing that, in spite of all its freedom and equality, the Athenian democracy in its foreign policy was not less eager to dominate over weaker states than any other form of government, and that in internal affairs a privileged minority dominated a majority which had no rights. Bolkestein ends by asking: "Is there anyone who denies this?" 1 That was in I93 I. I have the impression from recent literature that, after a quarter of a century, we have to answer Bolkestein by saying that many admirers of ancient Hellas try to make the Greeks appear better than they were, and in so doing do violence to the historical facts. The history of the last two decades has very probably helped to bring the good sides of Greek civilisation in the political and social fields more to the fore in Western Europe. Atrocities such as have occurred (and still do occur) in totalitarian states have made our world a less pleasant place to live in, and they have done more damage to human dignity than was apparently ever the case in the Greek world of the classical age.

And yet there is still a misconception, an idealisation, which cannot be maintained on closer inspection. If there is one thing which contemporary history has taught us it is that the dividing line between civilisation and barbarism is dangerously thin. Greek people sometimes attained heights which fill us, their heirs, with awe; on the other hand there are times when we are astounded at their barbarian acts and ideas. Why should we stifle this astonishment? If we do so we gain nothing and lose much. In a world which, for the most part, does not claim descent from Greek civilisation, we should rightly appear to be advocates in our own cause, and to some extent champions of what is evil. We must therefore pursue a different course. We ought no longer to speak of the Greeks as a universally glorified collective noun, but rather of Greeks, individually or (only after thorough research) in a certain form of collectivity; on no account of the Greeks as an entity covering a thousand years of history; not even as an entity of three or four centuries.

1 Mens en Maatschappij, 7, I93 I, p. 386. 
A particularly eloquent example, in this connection, is provided in the social history by the innumerable dissertations on slavery in the ancient world. It is impossible to discuss this question here as a whole, but it may be seen from what follows that this sort of tendency is visible among almost all those who are engaged in research on this subject. The sources speak of differences in the position of the slaves; sometimes the slave was despised and was treated accordingly; at other times, however, we find a more kindly view taken of him, and his lot is in no way without prospects of improvement. The modern historians, in so far as they are the victims of their own desire to generalize, turn to sources in which one of these two points of view occupies pride of place, and attach no value to data which might detract from the consistency of their general picture. The oft-quoted words of Zimmern are no exaggeration: „Everyone has his own theory of slavery. But, here as elsewhere in the fragmentary state of our knowledge of Greek life, no one has a touchstone by which his theory can be tested. Every decade or half decade sees a new book on the subject; the same authors are ransacked; the same evidence is marshalled; the same references and footnotes are transferred, like stale tea-leaves, from one learned receptacle to another; but there is a most startling variety about the resultant decoctions." ${ }^{1}$ The man who wrote this fell, nonetheless, a victim to the evil he censured. Like many another he tried to give a unified picture of a complex phenomenon. The conflict over the correct attitude towards slavery among the Greeks still rages, and it seems as if it has redoubled in vigour within the last year or two. ${ }^{2}$ This unsatisfactory state of affairs is, I am convinced, the result of one fundamental mistake, i.e. an over-simplified view of ancient society. It cannot of course be denied that social relationships in the Greek city state were less complex than those in our modern world of Western Europe. But because this difference has been so repeatedly emphasised, a simplicity of structure has been imposed on the older civilisation which does less than justice to the great variety visible in ordinary life in the ancient world. One may be ready to draw a distinction between the domestic slaves and those in the mines in the 5 th century Athens; the first are supposed to have been well, and the latter badly treated. But it can easily be forgotten that even this twofold division is far too much of a generalisation.

1 A. E. Zimmern, Solon and Croesus, 1928, p. 106. These words were already quoted by W. L. Westermann in Harv. Stud. in Class. Philol., Suppl. I, 1940, p. 452, and by W. K. Pritchett in Hesperia, XXV, 1956, p. 276.

2 Symptomatic of this is G. E. M. de Ste Croix's criticism (in Class. Rev., N.S., VII, I957, pp. 54-59) of W. L. Westermann's The Slave Systems of Greek and Roman Antiquity, Memoirs of the American Philosophical Society, vol. 40, 1955. 
Even though the data are not numerous one ought to begin by drawing up a list of the professions in which slaves were employed, and then try to establish the social position of each group. It is not valid to object that this would lead to an underestimation of the ancient Greeks. Even in a less complex society, like that of Crete in the 5 th century, the number of different social groups among the slaves exceeds two. ${ }^{1}$ Readers acquainted with recent data concerning property and tenure in Mycenaean Pylos would surely agree that the social situation described in these very early documents was varied and complex. ${ }^{2}$

A level of civilisation which rises far above anything appearing elsewhere in the same period, is not attained without a struggle. It is a mistake to believe that in Greece, or even in Athens, there lay a fertile soil, cleared of weeds, ploughed and watered, ready to receive the seed of civilisation. Those who survey a civilisation of the past, often attribute its flowering to the existence of that prepared soil. Such an explanation is sometimes not entirely without foundation, but more often than not the prize of civilisation has been won with difficulty; often the peak is reached in spite of, and not because of, certain factors. In our time the Greek achievement is explained as having been made possible by positive factors, thanks to the freedom of the city states, a freedom guaranteed by their constitution. Here again I have no wish to deny the validity of such an explanation but I ask once more: Is this the whole truth? If there were an "in spite of", the glory that was Greece would appear to me at any rate even more impressive. I believe that such restraining factors existed and that very often Greeks obstructed the Greeks, even in Athens, the Hellas of Hellas. For this reason Bickerman's complaint is at one and the same time both a warning and a challenge to all who wish to become acquainted with Greek civilisation in all its aspects: "When will historians stop speaking generally of Greeks, Romans, Jews, British, Russians, etc., as if peoples were, like homogenized milk, made uniform by the Creator?" 3

${ }^{1}$ See, inter alia, R. F. Willetts, Aristocratic Society in Ancient Crete, 1955, in particular pp. 52 et seq.

2 From the already considerable literature on the subject I only mention $\mathrm{L}$. R. Palmer, Achacans and Indo-Europeans, Oxford, I955; M. Ventris and J. Chadwick, Documents in Mycenaean Greek, Cambridge, 1956, pp. 232-274 (and the review of this work by Palmer, Gnomon 29, 1957, p. 570); the searching analysis of E. L. Bennett, The Landholders of Pylos, AJA, 60, I956, pp. I03-I33; W. E. Brown, Land Tenure in Mycenaean Pylos, Historia ,V, 1956, Pp. 385-400; M. I. Finley, Homer and Mycenae: Property and Tenure, ibid., VI, 1957, pp. 133-159; E. Will, Aux origines du régime foncier grec, REA, 59, 1957, pp. I-50.

3 Class. Philol., XLV, 1950, p. 44. 
It would presumably be agreed that distinctions must be drawn between the inhabitants of certain parts of ancient Greece. Athenians and Spartans differ from each other in so many respects that there could be no objection to distinguishing between the two states where society, culture and constitutions are concerned, even in the days when Greek culture was at its best. In our readiness to emphasise such distinctions we are, consciously or unconsciously, influenced by the desire to lend an even greater emphasis to the glory of Athens in contrast to Spartan narrow-mindedness. And it is with the glory of Athens that we are also here concerned.

In a democratic city state no difference is made between the political rights of rich and poor. Isonomia, equality before the law, existed for all citizens of Athens (aliens and slaves for present purposes being left out of consideration). And yet social differences existed between the citizens, differences which are too often forgotten when Greek (i.e. Athenian) democracy is praised. This is difficult to understand, for it is this very social inequality which accentuates the fact that the political equality was something precious, something which had been acquired with difficulty and which always remained insecure: they enjoyed political equality in spite of social inequality. Where must we look for this social inequality?

Arguments can be brought forward which seem to disprove its existence. The studies in terminology, in which the Dutch scholars of Greek history excelled some years ago, have demonstrated that the poor, the penites, were the people who earned their living with their hands. ${ }^{1}$ These included not only the artisans but also the small farmers. Equality before the law guaranteed them a place as full citizens, and the transition from one social level to another between the "poor" and the well-to-do was gradual; the extremes were not so widely separated as in later times.

Nevertheless, there did exist a deep social distinction which is not only to be found in the literature of an aristocratic or an oligarchic character, but which also becomes apparent from numerous symptoms. Members of old families were preferred for certain offices, and bomines novi were attacked on the very score of their social origin. Various priestly functions remained in the hands of leading families, and a rôle in processions and in religious ceremonies was reserved

1 J. Hemelrijk, Penia en Ploutos, Diss. Utrecht, 1925 ; J. J. van Manen, Penia en Ploutos in de periode na Alexander, Diss. Utrecht $193 \mathrm{I}$. The data contained in both these works and in numerous other Utrecht theses - as well as the results of his own researches - were used by $\mathrm{H}$. Bolkestein in his book Wohltätigkeit und Armenpflege im vorchristlichen Altertum, 1939. 
for girls of distinguished birth. Even in the heyday of democracy not all offices were open to everyone. The people themselves, moreover, tended to show a preference for men of higher birth when choosing their leaders. ${ }^{1}$ Aristophanes was not the only one to take vulgar advantage of the fact that Cleon and other politicians belonged to a less exalted social level. Even Demosthenes, a zealous democrat, jeered at the humble parentage of Aeschines. ${ }^{2}$ The orators of the 4th century, who were often politically influential, were generally members of well-to-do families. ${ }^{3}$

It happened only rarely that a self-made man like Phrynichus or Aeschines acquired political influence. The careers of rich men and aristocrats were not hindered by comic poets and orators, as were those of poor men or men of inferior birth. Equality in the eyes of the law, strictly maintained by the democratic institutions, prevented this abuse from having serious political consequences. Nevertheless, social inferiority definitely did exist. One may wonder why the penètes, who had the majority in the assembly, behaved in so snobbish a manner, why they laughed when in the law courts and in the theatre the humble origins of leading figures were criticized. Why did the members of the jury in the people's courts not take exception to this sort of argument? The answer is, I believe, that the democracy in Athens (and elsewhere) recognized class distinctions based on wealth, which, although not dangerous politically, accentuated the social differences. It is no exaggeration to say that it was due to the lowest class, the thetes, that the Athenian empire became great; they served as rowers in the fleet. But the thetes knew of no greater ideal than that of leaving the lowest class and becoming a farmer, zeugites. The colonies of Athenian citizens on allied territory were based on the zeugite status. Thetes who were sent abroad, were in this way raised from the lowest class. This step up the social ladder was made by 10.000 citizens during the period of the Athenian Empire, ${ }^{4}$ a considerable number when compared with the total number of about I $50.000 .^{5}$ This "colonizing"

1 Aristotle Pol. 1273 b; for the $4^{\text {th }}$ century, see J. Sundwall, Epigraphische Beiträge, Klio Beiheft IV, I906, par. 2, 5 and 8.

2 Dem. XIX, 239; Compare A. H. M. Jones, The Athenian Democracy and its critics, in: Cambr. Hist. Rev., XI, I953, pp. I-26 (now republished in Athenian Democracy, Oxford 1957, p. 4 I ff.).

3 Sundwall, op. cit., par. 8, pp. 59-84.

4. H. M. Jones, The economic basis of the Athenian Democracy, Past and Present, I, 1952, pp. I3-3 I (republished in Athenian Democracy, p. $3 \mathrm{ff}$., I68ff).

5 A. W. Gomme, The Population of Athens in the 5th and $4^{\text {th }}$ centuries B.C., I933, p. 26, gives reliable numbers. For 480 he counts 140.000 citizens, for fifty years later I72.000. 
measure signified, moreover, a strengthening of the hoplite army, the civil militia from which the lowest class were excluded. - Let me hasten to add that we, too, are well acquainted with social distinctions in our own democracy. In a modern, popular neighbourhood, for example, it is well recognised that more rent has to be paid for a better house. If one lives in a more expensive house, or even on the more expensive side of the same street, then one is likewise better. Social distinctions are assiduously maintained, especially by the "class" next in order. The difference between our modern Western democracy and that of the Greeks, however, is that the social distinctions in the latter were rooted in the constitution, by the existence of census classes laid down in it. The archonship was opened to the zeugitai in $458 / 7$, and even the radical democracy never went any further. It conflicted with a deep-seated social sense that a labourer completely without property should occupy the office of president, king, or chairman of a legal bench, and should later take his seat in the Areopagus. ${ }^{1}$ It is therefore all the more admirable that the political rights of the citizens were guaranteed nevertheless. For it was no insignificant threat to real democracy that the Athenians who submitted their names for the ballot for an office had to make a declaration that they did not belong to the thetes. ${ }^{2}$ Apparently those who belonged to the lowest class did not wish it otherwise. They were more interested in the reaching a higher census class, i.e. that of the qeugitai, than in the acquisition of the right to occupy offices that would automatically accrue to them along with the higher status. The Athenian constitution thus never officially abandoned its social prejudices.

Vain attempts have been made, in a blind adoration of the Athenian democracy, to find a way round the conclusive force of the documentary evidence. ${ }^{3}$ Some, for example, maintain that the declaration required for the tenure of official posts, namely that one did not belong to the thetes, was a farce, and believe that the authorities turned a blind eye when false statements were made; in this way the disqualification of the thetes was supposed to have been overcome by a legal fiction, since the declaration though required was not verified. But such a view is not supported by any data in the sources; ${ }^{4}$ there is nothing to

1 Ed. Meyer, Geschichte des Altertums, III, p. 573.

2 Aristotle, Ath. Pol., 7, 4.

8 Survey of views in Busolt-Swoboda, Griechische Staatskunde, II, I926, p. 899, note. 2 4 Plut. Arist. 22 cannot be properly cited here. According to this passage, a decision is supposed to have been taken by the people immediately after Plataea (479), by which the selection for official posts was opened to all Athenians of whatever class. But we know that it was only in $458 / 7$ that the archonship became open to the zergitai (Arist. Ath. Pol. 26). Moreover, selection is not an accurate term; the ballot also existed. Ps.-Xen., Ath. Pol, seems 
indicate that the regulations were in any way circumvented. But for the present purpose it is unnecessary to deal with this question. In whatever way one may interpret Aristotle's words, the implication remains that, according to the letter of the law, the thetes could not be elected to any magistracy. In the course of time the census of the zeugitai was decreased, and, it further lost significance by reason of the decline in the value of money. In the fourth century the census was I 50 drachmas (instead of the 200 of Solon's legislation). But this is no argument against the continued existence of a social prejudice translated into law. The lowering of the census proves, tather, that an attempt was made to withdraw as many citizens as possible from the inferior class of the thetes. But the fact of inferiority remained. Perhaps this might be the explanation for the fact that the scanty demographic data about Athens mention no numbers for the thetes, in contrast with the hoplites, even though the former were indispensable as rowers in the fleet. ${ }^{1}$

One sphere in which the lower classes were not forgotten was that of religion. In many cities they had a certain cult function to perform, not as a group, but through the choice of one individual from the group every year. In various Ionian cities there took place every year, as we know, the festival of the Thargelia. ${ }^{2}$ This was held on the sixth day of the month Thargelion and is defined as a feast of purification, sometimes combined with a fertility rite. In its oldest and crudest form the sacrifice made on that day was a human one, meant to reconcile the city with the gods. The results to be expected from the sacrifice depended to a great extent upon the willingness with which the expiatory victim met his death. As a rule, therefore, only those for

to confirm the fact that the thetes, were not excluded from official posts. I agree, however, with A. W. Gomme when he states that this enemy of democracy exaggerates deliberately (Harv. Stud. in Class. Philol., Suppl. I I940, p. 21 I et seq.). As far as its historical value is concerned, the "Old Oligarch's" political pamphlet has been viewed in totally different lights. Small wonder that he is highly esteemed in totalitarian-minded circles. But also scholars of untarnished reputation praise "den erstaunlichen Scharfblick und die unheimliche Objektivität, mit denen er die athenische Demokratie und ihr Funktionieren seziert" (M.P. Nilsson, Die hellenistische Schule, 1955, p. 5). Personally, I entirely support the opinion of Gomme: "not a writer to be relied upon in general or in detail" (Commentary on Thucydides, I, 1945, p. 24I). Closer research reveals that no value can be ascribed, either, to Isocr. XX, 20, Lys. XXIV, 13 and Ps.-Dem. LIX, $7^{2}$, passages which are sometimes quoted in order to deny the existence of the barrier for the thetes. Loenen, op. cit., pp. I $81-182$, gives a brief and accurate survey of the whole problem.

1 See Thuc. II, I3, 8 and the Commentary II, I956, ad loc. (Gomme); further Philochorus fr. I I 9 and the comment by Jacoby in FGrHist, IIIb, Suppl. I, p. 464, with the review by Gomme in Class. Rev., 1956, p. 25.

2 See Nilsson, Gricchische Feste, 1906, p. 106 et seq.; Deubner, Attische Feste, p. 179 et seq. 
whom life had become a burden, men who were starving or hopeless invalids, were willing to be sacrificed. The prospect of a year's provision of good food (white bread, figs and cheese) amply compensated for the death that was to follow. (We need not ask what famine conditions must have existed to persuade a poor man to exchange his life for one year's provision of food). The victims in no sense enjoyed the respect of their fellow citizens. They were referred to in terms of vulgar abuse, in words which expressed the most profound contempt. ${ }^{1}$ The best known example, although of a much later period, is the word "offscouring" in St. Paul's first epistle to the Corinthians: "being reviled, we bless; being persecuted, we suffer it: Being defamed, we intreat: we are made as the filth of the world, and are the offscouring of all things unto this day". ${ }^{2}$

There is no need to follow up the question of whether human sacrifices were made in democratic Athens. The scanty data indicate, in my opinion, that this was not so. One may likewise pass over the question as to whether the scapegoats, or pbarmakoi did no more than purify the city or whether they were also believed to promote fertility. For social history it is of importance that people who were looked upon as inferior (but who were not slaves) were elected to be sent out from the city during the festival. They had no hope of being granted permission to return later. ${ }^{3}$ Who were these people? One of the sources mentions "people against whom nature had conspired" (i.e. defectives), and in Athens we hear of "the unemployable, and people without genos" ", this last word being explained by modern scholars as "a bastard, son of an alien mother and an Athenian"; as such the child could not be a member of a family, he was an agennos. 5 The term "unemployable" probably referred to invalids (not war-invalids; these received a pension from the State and were held in respect).

Whilst data from elsewhere indicate that the best were chosen for this substitution-offering - as in the saga of Codrus and in the biblical story of Jephtha's daughter ${ }^{6}$ - the persons selected as pharmakoi were inferior. In this connection, but not in Athens, mention is made of criminals who had already been sentenced, of starving wretches who were glad to end their lives with a good meal, and also of deformed persons.

1 Such invectives are thus used by Eupolis $\mathrm{Fr}$. $\mathrm{II}_{7}(\mathrm{~K})$.

2 I Cor. 4, I3. Compare the comments of H. Lietzmann in the Handbuch zum N.T., ad loc.; and Stählin in Theol. Wörterb. zum N.T., s.v. peripsèma (vol. VI, 2, 1955, pp. 89-91).

3 That return was impossible is proved by [Lys.] 6, 53 .

4 Passages in Gilbert Murray, The Rise of the Greek Epic ${ }^{2}$, 1911 , p. 327.

5 This explanation in V. Ehrenberg, The People of Aristophanes 2, 195I, p. I6I.

- Lycurg. Leoc. 84-87 (Codrus); Judges I I, 34-40 (Jephtha's daughter). 
One can well appreciate that a titual of this kind hardly squares with the ideal picture of the Greeks. Gilbert Murray, the embodiment of the tendency to idealise and to generalise about the classical period, has attempted to free the Athenians at least from the blemish of this custom. He compares the Thargelia with Guy Fawkes Day and the banishment of the pharmakoi with the burning of the "Guy", the effigy representing the incendiary. ${ }^{1}$ Murray's comparison is not a happy one - an effigy is not a human being -; and his argumentation is unsound, even though he presents all the data with a disarming honesty. He cannot escape the facts. In democratic Athens in the time of Aristophanes a pharmakos was banished for ever at the teast of the Thargelia in fulfilment of a religious duty which the city could not escape. ${ }^{2}$ On the other hand, it is to the credit of the Athenians of the golden age that there are no indications of a similar banishment taking place on any other occasion (in times of emergency or misfortune). ${ }^{3}$

In studying the religion of the Greeks one is frequently faced with the problem of guilt and purification from guilt. One of the greatest political controversies in democratic Athens cannot be properly understood without an appreciation of the deep-seated fear of a blood-guilt which must be expiated. The family of the Alcmeonids, pioneers of radical democratic ideas, is always described as the "polluted" because of a real or presumed guilt incurred at a time long past. Ancient historians devote much time and patience to demonstrating not that the belief in blood-guilt was superstition (as might perhaps have been expected in the rational fifth century), but that the Alcmeonids were innocent and that the most famous scion of their house, Pericles, was therefore not a "polluted" man. ${ }^{4}$ At Athens, furthermore, the influence of religious ideas also served to determine political and military action. The mutilation of the Hermae, when the disastrous expedition to Sicily had been decided on, is well enough known; but some years previously the entire foreign policy of the city had depended, at one moment, on the interpretation given to an earthquake. ${ }^{5}$

Thucydides provides the clearest proof of the gieat influence of omens and oracles during the Great Peloponnesian War. ${ }^{6}$ It is one-

1 Op. cit., p. 326, 329.

2 Gebhard in Pauly-Wissowa under Pharmakoi (2. Reihe, V, Kol. I29I) rightly against Murray. See also Nilsson, GGR, ${ }^{2}$, 1955, p. 107.

3 This is rightly indicated both by Deubner, op. cit., p. 185 , and by Nilsson, loc. cit.

- Hdt. V, $7^{\circ}$ et seq. and Thuc. I, I 26 are the main sources; see F. Jacoby, Atthis, 1949, in particular p. $186 \mathrm{et}$ seq. for the traditions among the Atthidographers.

5 In 420; see Thuc. V, 44-46.

Thuc. II, 8,$2 ; 17,2 ; 54 ; \mathrm{V}, 26$; VI, 70, 1 ; VII, 50, 4; 79, 3 . 
sided to consider the historian's contempt of this superstition as "typically Greek". And to believe that his "characteristic reliance on the intellect" is also "characteristically Greek" 1 is equally unhistorical. One may find examples enough in Thucydides' historical writings to give the lie to this sort of idea: the invocation to the gods made by the Plataeans, by the Melians, by Nicias on the occasion of the retreat from Syracuse, ${ }^{2}$ vain though they were, were uttered by people of whom the majority were "ordinary" people, men and women in distress. If Demosthenes really used the words which Plutarch puts into his mouth, ${ }^{3}$ namely that Pericles and Epaminondas did not believe in oracles, but considered a belief in them to be an excuse for cowardice, then the statesmen he named are not truly representative of the Greeks; they were Greeks, indeed, but so were their fellow citizens and contemporaries, who for the most part attached sincere credence to the oracles. ${ }^{4}$ And these, too, it was who knew within them the fear of religious impurity, who celebrated the Thargelia, who banished the pharmakoi.

We have seen above that the pharmakoi could be people "against whom nature had conspired". It is generally accepted that these words refer to the deformed. In Greece the state took upon itself the care of those members of the community who had been maimed in battle. It is to its everlasting honour that the Greek state did not allow those who had served their country with life and limb to waste away in misery. This rule, as I see it, deserves all the more praise, when we consider that other maimed or otherwise deformed persons were more likely to be treated with hostility by the community. In dealing with this group in greater detail it is not my intention to censure the Greeks, but rather to emphasize that it was by no means self-evident that war invalids should be well cared for. Here again, it shows how dangerously thin is the dividing line between humanity and cruelty.

Hesiod ${ }^{5}$ describes the fortune of a city whose citizens are honest men. One of the good things which falls to their lot is that the women bear children who resemble their parents, ${ }^{6}$ in other words: healthy

1 J. H. Finley, Thucydides, 1942, p. 3 Io.

2 Thuc. III, 58; V, 104-I05; VII, 77, 3-4.

3 Plut. Dem. 20.

4 Compare M. P. Nilsson's summing-up, for the sth and 4 th centuries, in Cults, Myths, Oracles, and Politics in Ancient Greece, 195 x, p. 133 et seq.

5 Erga 225 et seq.

- Line 235. These and other literary texts, though unfortunately not the inscriptions, have been treated by Mlle Marie Delcourt, Stérilités mystérieuses et naissances maléfiques dans l'antiquité classique, Bibl. de la faculté de Philos. et Lettres de l'Université de Liège, fasc. LXXXIII, 1938. 
children, not terata or portenta. The significance of this line is entirely misunderstood if it is translated as: "children who resemble their fathers", i.e. children who, because of their resemblance to their legitimate fathers, furnish proof that their mothers have not committed adultery! ${ }^{1}$ On the contrary, it is here a question of malformed children who are seen as a curse on the community. Aeschines ${ }^{2}$ has preserved an ancient curse said to date from the First Sacred War in the time of Solon. At that time the men of Cirrhae had profaned the temple at Delphi, and an oracle had ordered that, in punishment, their country was to be laid waste. The Amphictyons promised to do this, and with a solemn undertaking laid a curse, in the names of Apollo, Artemis, Leto and Athena, on all who might fail to carry out their religious duty. In this curse occur the words: "That the women may bear no children who resemble their parents". An interesting parallel, expressed in the same words, occurs in the oath which the Athenians are supposed to have sworn when they were on the point of joining battle with the Persians at Plataea. Although it is practically certain that the oath itself is unhistorical, this is irrelevant for the present investigation. Here we are concerned with the mentality of the Athenians who formulated this oath and who preserved it on a column in the deme Acharnae. ${ }^{3}$ Basing his arguments on a number of inscriptions from many places in the Greek world, Louis Robert ${ }^{4}$ has demonstrated the general existence of these same imprecations, even though the formulation of them sometimes differs from that at Acharnae.

To have given birth to deformed children was generally looked upon as a punishment, and it is understandable that the community took measures against these unfortunates whenever possible. The individual is a member of the community: what injures him, injures it. In Sparta, where the individual had less freedom than elsewhere, the decision as to whether a new-born child should be permitted to live was a right reserved to the oldest members of the father's phyle. If the child was well-formed and strong it was allowed to live. But if it was deformed or weak, it had to be sent to the Apotbetae, a precipice near the Taygetus. ${ }^{5}$ Those born deformed in Athens likewise faced an unpleasant fate. Even if no positive data about this were available there

1 E.g. Mazon, and also Gow ad Theocr. XVII, 43, et seq., where he quotes Hes. (Theocritus ed. with translation and commenatry $\mathrm{II}^{2}$, I 95 I, p. 334).

2 c. Ctes. I I I.

${ }^{3}$ D. W. Prakken, Note on the Apocryphical Oath of the Athenians at Plataea, AJP, LXI, I940, pp. 62-65.

4 Études épigraphiques, 1938, pp. 307-308.

5 Plut. Lyc. XVI. Compare P. Roussel in REA, 45, 1943, pp. 5-17. 
exists an argumentum $e$ silentio, which in this particular case is of considerable significance, although as a rule this type of argument may be thought dangerous. In his Respublica Lacedaemoniorum Xenophon wrote about those customs in Sparta which would strike other Greeks as being different from their own; in this monograph he makes no mention whatever of the attitude towards the deformed. Apparently what happened in Sparta was commonplace. But there are also positive indications that, in this connection, the same sort of thing in fact occurred in Athens. Theaetetus maintains, in Plato's dialogue of the same name, ${ }^{1}$ that knowledge is nothing more than perception. This thesis is, says Socrates, Theaetetus' new-born infant and he, Socrates, is the midwife. Pursuing the comparison, he believes that an Amphidromia (i.e. the feast at which the child was carried around) should be held in order to see whether this new-born child was worthy of being nourished or whether it was nothing more than wind and lies. If the latter, it must be exposed. And Socrates concludes with the query: "Will you endure his being criticized before your eyes and not become angry in case your first-born be taken away from you?" The whole comparison makes nonsense unless the custom of abandoning deformed children really existed. Even a first-born child did not escape it. A father parted reluctantly with his first-born: but he had to, and he did, but with reluctance since it was his first-born. A Scottish scholar has said of the concluding words of this passage: "It suggests the reluctant exposure of the first-born, because he is a weakling, a defective". ${ }^{2}$ But this explanation shifts the emphasis to the first-born; it lies, however, on the defective. The writer should have said: "It suggests the exposure of a weakling, a defective, reluctantly because he is the first-born."

Other passages in Plato, the interpretation of which, for that matter, is uncertain, are deliberately not taken into consideration here. ${ }^{3}$ For we do not know to what extent the Platonic concepts of the ideal state ever mirror what was the reality at Athens. The passage from the Theaetetus, however, clearly shows that it was a common practice to abandon defective children. This is indirectly confirmed by Aristotle, ${ }^{\mathbf{4}}$ who demands that an abnormal child be repudiated and "made away with" after its birth. Aristotle gives further information about another custom, the exposure of (healthy) children in order to remedy too great an increase in population; on this point he says that there are states where the "moral standards" object to such a practice.

1 I6oc-i 719.

2 Gomme, Population etc., p. 82.

3 Tim. Iga; Resp. $460 c$.

4 Aristotle, Pol. I335b. 
Apparently in his time it was generally considered both necessary and natural that newly-born defective children should be abandoned, for in this provision he does not mention a "standard" that was contrary to custom.

A voluminous amount of literature on the exposure of children in Greek antiquity has gradually been built up. ${ }^{1}$ Evidence from the classical period in no way allows us to suppose that the custom was general as far as healthy children were concerned. On this point Isocrates speaks in unequivocal terms. In his Panatbenaeicus ${ }^{2}$ he sums up offences that did not occur in Athens; included among these is the abandonment of new-born children. No matter how rhetorical this passage is thought to be, it must be taken seriously. What is more, it is confirmed by Aristotle: in Athens (even though he does not mention the city by name) the "moral standard" (taxis tôn etbôn) was opposed to the exposure of children purely and simply on grounds of over-population. This is in striking contrast with the attitude towards children cast out by reason of deformity. It is indeed but a thin partition that separates humanity from cruelty. If it is the regular thing to reject defective children, one is standing on a slippery slope; other reasons beside deformity may then be found for not accepting children into the community, economic reasons for example. Thus Aristotle finds himself able to mention as a noteworthy fact that the Egyptians reared all their children $;^{3}$ Strabo was to repeat this in the first century. ${ }^{4}$ And in the same way, in the second century of our era it can be accounted worthy of special record that the exposure of children was forbidden in Thebes; ${ }^{5}$ and in the fifth century that this was permitted in Ephesus only if the father was a pauper. ${ }^{6}$

Let us however return to the Golden Age of Athens. There are no grounds for suggesting that the practice of exposing children was generally prevalent at this time. If, however, a child was defective, then other sentiments, such as, for instance, a superstitious fear of the "abnormal", probably entered into the picture. In such cases parental love no longer counted; all that was considered was the interest of the community, which might be threatened by the "abnormal" child.

$$
\text { * * }
$$

1 Specially H. Bolkestein in Class. Philol., XVII, 1922, p. 222-239; A. Cameton in Cl. Rev., XLVI, 1932, pp. 105-II4.

$2 \mathrm{I} 2 \mathrm{I}$.

3 Fr. 283 (R).

824 .

5 Ael., VH II, 17.

- Proclus in Poet. min. gr. II, 305. 
The history of humanity does not reveal a uniform evolution from a lower to a higher level. The zigzag line, which we can sometimes distinguish only vaguely, weaves its way through the history of man, and in the process through Greek history as well. That the Greeks could be humane, that they were able both to establish and to uphold the dignity of man, that they could serve and honour their fellowmen, that they could respect the convictions of others - all this can be proved from their literature from Homer onwards. On the other hand, that they could be cruel and that they could trample human dignity underfoot can also be demonstrated by examples drawn from their literature. Both of these opposing forces reveal themselves in all that concerns man. The observation of this truth is a fascinating privilege which the historian owes not least to his studies. However, to postulate a uniform evolution in the ancient history of the Near East and Greece, with the Greeks at the summit of it, born out of nothingness, but suddenly in being as complete creatures of lofty moral standards resembling the Athena of mythology, the goddess born fully armed out of her father's head, is to fill the stage of classical Greece with a mythological tale of one's own making, and to tread the facts of history underfoot. And, what is the worst point about this way of thinking, the Greeks are denied the honour which is their due. A difficult struggle to attain something which has to be wrested from one's own egoism, is more honourable than an exalted superiority that has always been one's possession.

Many may consider it appropriate to stress only the brighter side of the Greeks considered as a whole. They believe that in doing so they are serving the future of classical education. This is a misconception. The future of humanistic studies is not served by transforming, in an unhistorical manner, Greeks into the Greeks. In I 9I I the attack on such illusions was successfully begun by A. E. Zimmern in The Greek Commonwealth; in this book, for the first time, it was described in what poverty and filth, judged by our standards, the population of Hellas lived in its most palmy days. The true facts have justifiably won a general appreciation, and it is now realized that these features in no way detract from the Greek achievements; indeed, it has proved very much the contrary. But Zimmern did not go far enough; and perhaps he won over the classicists for the very reason that he did not go any further. Forty years later his compatriot Dodds wrote The Greeks and the Irrational. In spite of the general approbation with which this book was received, many are (not yet) entirely convinced. Why not? Because, though by no means lacking in appreciation for those characteristics which distinguish the Greeks from the barbarians, 
Dodds has pointed out traits in their character and way of life which one would prefer not to recognize in them. "The Greeks are not a primitive people," is advanced as the usual qualification. Just as if psychology had not taught us, and as if religious phenomenology had not confirmed, that the "mentalite primitive" is a reality, and that not one people, not even the Greeks, have been immune from elements which have been present in every society we know today. ${ }^{1}$ What Dodds did for the history of religion was not carried through to its conclusion, and in many other departments of Greek life, especially in that of social history, it still remains to be undertaken. It is one of the tasks that await the historian of Antiquity. The time is ripe for it and, as a reaction to the contemptuous generalisations accepted nowadays in many countries, it is a work of research most urgently needed. ${ }^{2}$

1 See Dodds himself - anticipating his critics - in the Preface of the book mentioned. ${ }^{2}$ I wish to thank Mr. A. G. Woodhead (Cambridge) for reading and criticising an earlier draft of this paper, and for his corrections of the typescript. 